\title{
THE IMPACT OF FINANCIAL STATEMENT ANALYSIS ON THE PROFITABILITY ASSESSMENT (APPLIED STUDY OF KIRKUK COMPANY FOR PRODUCING CONSTRUCTIONAL MATERIALS)
}

\author{
Amanj Mohamed Ahmed \\ Darbandikhan Technical Institute, Sulaimani Polytechnic University / Sulaimani, \\ Kurdistan Region, Iraq \\ amanj.mohamed@spu.edu.iq
}

\begin{abstract}
The present study entitled "financial statement analysis and assessing the profitability of the Kirkuk's Company for producing constructional materials". The main goal of the accounting department in the firms is to prepare the reliable financial statements in order to make their valid balance sheets, income statements and cash flow statement. This paper determines the confirming effects of the financial statement analysis to assess the profitability of the Kirkuk Company. The data in this study is based on the secondary data and it collected from the past and present performance of Kirkuk's Company for producing constructional materials. To achieve the research goal, four categories of the financial ratios were utilized for testing the study's hypothesis. This group of ratios was applied to assess the financial situation of the company in the years between "2005 to 2011" by using different techniques of financial statement analysis. The results clearly show that, there are insignificant relationships between profitability with asset regulated and assets utilization. At the same times, there is a weak relationship between profitability and liquidity.
\end{abstract}

\section{Keywords}

Financial Statements; Ratios Analysis; Profitability

\section{JEL Classification}

M41; G15

\section{Introduction}

Financial analysis can be defined as the process of evaluating the financial condition of a company by analyzing its profitability, viability and stability (Sultan, 2014; Ravinder and Anitha 2013 Alani1 et al., 2013 \& Laitinen, 2006). It is also used to compare the company's performance with competitors (Sultan, 2014). As a result, after the war of Iraq of (2003) there is an increasing demand of using the financial analysis through the manufacturing companies in Kurdistan Region especially and in Iraq generally. Financial performance and profitability would be defined as measuring the results of the firm's operations and polices in monetary terms in evaluating the overall financial position of a company (Gibson, 2013), which is including balance sheet, income statement, current operation statements and cash flow. This study explains the above statements in details and applies the ratios for them.

In this paper, Kirkuk Company for producing constructional materials is selected. The company was recorded in the listed companies of Iraqi stock exchange with a code of (IKFP). This research also describes the profitability of the company. This is because financial statement analysis can be seen as an important tool that used by the various 
agents either internally to the company or who is coming as a part of the company as an external operating environment (Gibson, 2013). In addition, the ratios and formula can be used to calculate the performances which are derived from the information that is revealed by the periodic financial reports which is the balance sheet, income statements and the statement of cash flow (Gibson, 2013). Thus, the purpose of this paper is to find any impact on profitability that is caused by financial statement analysis. This paper organized as follows: section one, it is just to give a brief introduction about the topic. Section two gives the theoretical background while section three demonstrates some empirical framework. Section four shows research methodology and the nature of the data collection. The fifth section gives a summary of the results of financial analysis, the profitability and measuring the company's performance, and, finally, the conclusion can be drown from the above arguments.

\section{Theoretical background}

\section{The concept of financial statements}

According to (Gill, 1999), financial statements are the principal means of reporting financial information for internal and external users. In reality, both public and private traded corporations must comply with strict requirements for preparing financial statements. Generally Accepted Accounting Principles (GAAP) is the "ground rules" for financial statements and reporting as well. This standard provides a framework to show what information should be included in the financial statements and how should be presented. They are designed so that financial statement information about businesses is reliable and comparable. In order to have a functional understanding of finance, it is essential to thoroughly understand balance Sheet, income statement and cash flow (Nuhu, 2014; Sultan, 2014 \& Maggina, 2008).

\section{Financial Ratios}

The concepts of financial ratio and proportion are fundamental to mathematics and important in many other fields of knowledge. Many phenomena can be expressed as some proportional relationship between specific variable, often leading to some new unique entity (Barnes, 1987). Conceptualization and comprehension of these concepts, not to mention skills and competence in using them, facilitate mathematic awareness (Barnes, 1987). Even, more importantly, these skills foster the ability to use relational reasoning, otherwise known as proportional reasoning, which is crucial to the development of analytical mathematical reasoning (Barnes, 1987).

\section{Profitability Ratios}

Profitability ratios is a class of financial metrics that are used to evaluating the corporation's skill to make receiving likened to its expense and other applicable costs sustained throughout the period of time. It can be used to measure the profitability, which is simply shows the capacity of the firm to make a profit (Lasher, 1997; Tulsian, 2014; Rashid, 2018 \& Adebisi et al., 2016).

\section{a. Return on Asset (ROA) Ratio}

This illustrates how the company generates profit as a result of using assets. (Gadoiu, 2018). It can be calculated as follow:

Return on Asset (ROA) Ratio $=\frac{\text { Net Income }}{\text { Total Asset }}$ x 100 (Gibson, 2013 \& Ross et al., 2013) 


\section{b. Return on Equity (ROE) Ratio}

Return on equity ratio (ROE) is treated as an important measure of a company's earnings performance. The ROE tells common shareholders how effectively their money is being employed. With it, one can determine whether a firm is a profit-creator or a profit-burner and management's profit-earnings efficiency (Kijewska, 2016). Return on equity can be calculated as follow:

Return on Equity $\left(\right.$ ROE) Ratio $=\frac{\text { Net Income }}{\text { Stock Holder Equity }} \times 100$ (Gibson, 2013 \& Ross et al., 2013)

\section{c. Operation Profit Margin (OPM) Ratio}

This ratio can be used to measure the ability of a company towards operating and nonoperating expenses (Shilpa et al., 2017). It can be calculated as follow:

Operating Profit Margin Ratio $=\frac{\text { Incom From Operation }}{\text { Sales }}$ (Gibson, $2013 \&$ Ross et al., 2013)

\section{Liquidity Ratios}

The liquidity or solvency ratios are focused on a firm's ability to meet its short-term debt and obligations. In other words, it can help to know the resources that are available for a company to use in order to pay its current obligation and expenses. (Costea \& Hostiuc, 2009 \& Tugas, 2012).

\section{a. Current Ratio}

The current ratio is calculated by dividing current assets on current liabilities. It is also known as a working capital ratio that measures a business's ability to pay short-term libalities (Bodie, et al., 2009).

Current Ratio $=\frac{\text { Corrent Asset }}{\text { Current Liability }}$ (Gibson, $2013 \&$ Ross et al., 2013)

\section{b. Acid- Test Ratio (Quick Ratio)}

Acid- test ratio is a one of the liquidity ratio that measures the ability of the firm to use current assets without inventory to cover current liability (Rashid, 2018). It means that illustrating the company to meet its immediate financial requirements. Hence, this advises that a business is over-leveraged, fraught to keep and raise sales, paying bills too fast, or collecting receivables too slow (Brigham \& Houston, 2014 \& Bragg, 2012). The Acid- Test Ratio formulated as a follow:

Acid-Test- Ratio (quick ratio) $=\frac{\text { Cash }+ \text { Account Receivable }}{\text { Current Liability }}$ (Gibson, 2013 \& Ross et al., 2013)

\section{Asset Utilization Ratios}

Asset utilization rations include: receivables turnover, days' sales in receivables, inventory turnover, days' sales in inventory, cash turnover ratio, total asset turnover ratio.

\section{a. Account Receivable Turnover Ratio}

Account receivable turnover ratio is amount of money that uncollected in a fiscal year. Every company must have a low amount of receivable in a transaction. Therefore, the company should collect their money in order to be used and invested in other sectors to make more profit (Gautam, 2013). The mathematic formula is:

Account Receivable Turnover $=\frac{\text { Sales }}{\text { Account Receivable }}$ (Gibson, 2013 \& Ross et al., 2013) 


\section{b. Days' sales in receivables}

This makes more sense and effect because it converts the above ratio for days (Gibson, 2013). This ratio formulated as follow:

Days' sales in receivables $=\frac{365 \text { days }}{\text { Account Receivable Turnover Ratiovable }}$ (Gibson, 2013 \& Ross et al., 2013)

\section{c. Inventory Turnover Ratio}

This can be used to measure how the quick your inventory is moving? It means how many times your basic inventory is replaced in a fiscal year (Gill, 1999). The mathematical formula is:

Inventory Turnover Ratio $=\frac{\text { C.O.G.S. }}{\text { Inventory }}$ (Gibson, $2013 \&$ Ross et al., 2013)

\section{d. Days' sales in inventory}

This can be applied to find the number of days that we need it to sell inventory, which means showing the efficiency of inventory (Dauderis \& Annand, 2014). This ratio has been formulated as below:

Day to sell inventory ratio $=\frac{365 \text { days }}{\text { Inventory Turnover Ratio }}$ (Gibson, $2013 \&$ Ross et al., 2013)

\section{e. Cash Turnover Ratio}

Cash turnover ratio is used to fix the amount of cash that is required to collect as a result of sales (Keythman, 2018). The formula is:

Cash Turnover Ratio $=\frac{\text { Sales }}{\text { Cash \& Cash Equivalent }}$ (Gibson, 2013 \& Ross et al., 2013)

\section{f. Total Asset Turnover Ratio}

Total asset turnover ratio is a term that shows the effectiveness of operation of total assets. It specifies how many times that the total assets turned for one year. In general, companies with high ratio tend to have low profit margins, while those with low ratio tend to have higher profit margins (Warrad \& Omari, 2015).The formula consists of:

Total Asset Turnover Ratio $=\frac{\text { Sales }}{\text { Total Asset }}$ (Gibson, $2013 \&$ Ross et al., 2013)

\section{Operating properties (Regulated Utilities) Ratios}

This group also called by "regulated utilities ratios" and is a kind of professional preparation in which a subsidiary company owns all the revenue-generating properties instead of the central company.

\section{a. Operating Ratio}

It can be defined as a corporation's working outlays and it is commonly used for business, which need a great percentage of revenues to keep operations. The calculated formula is:

Operating Ratio $=\frac{\text { Operating Expense }}{\text { Operating Revenue }}$ (Gibson, 2013 \& Ross et al., 2013)

\section{b. Funded Debit to Operating Property}

It is a corporation's debt ratio that will settle for more than one year. This form of debt is categorized as funded debt since it is funded by interest payment that is completed by the borrowing firm who terminated the term of the loan. It can be formulated as follow:

Funded Debt to Operating Property $=\frac{\text { Funded Debit }}{\text { Operating Property }}$ (Gibson, 2013 \& Ross et al., 2013) 


\section{c. Percent Earned on Operating Property}

Percent earned on operating property is an income ratio which is coming after operating of properties. It can be formulated as follow:

Percent Earned on operating Property $=\frac{\text { Net Income }}{\text { Operating Property }}$ (Gibson, $2013 \&$ Ross et al., 2013)

\section{d. Operating Revenue to Operating Property}

This ratio is basically an operating asset turnover ratio. In public utilities, the fixed plant is often much larger than the expected annual revenue, and this ratio will be less. (Gibson, 2013). It can be formulated as follow:

Operating Revenue to Operating Property $=\frac{\text { Operating Revenue }}{\text { Operating Property }}$ (Gibson, 2013 \& Ross et al., 2013)

\section{Hypothesis of the study}

H1: The financial statement analysis has a significant impact on the profitability.

$\mathrm{HO}$ : The financial statement analysis has not an impact on the profitability.

\section{Objectives of the Study}

The main objective of this paper is to:

(i) analyze the financial statement analysis by applying financial ratios for Kirkuk Company for producing constructional materials.

(ii) highlight the difference performances of Kirkuk Company for producing constructional materials.

(iii) suggest some recommendations for the managers of Kirkuk Company for producing constructional materials.

\section{Empirical framework}

This section shows related literature that was conducted by other researchers at the national and international levels.

The first study on validity of financial ratio was conducted by (Mc Donald \& Morris, 1985). They were focusing on two samples with three models, one of the sample was a single industry the other one linked with a random selected firm. For each industry, the researchers tried to find the application of homogeneity on proportionality. The result was clearly mentioned in their paper, even though financial ratio analysis is a great support for the company but for the comparisons, profitability and proportionality, financial ratios is not helpful. However, (Berry \& Nix, 2012) criticized the work of Mc Donald and Morris over time, over ratios and over industries.

A study managed by Laitinen (2006) demonstrates a framework for analyzing financial statements of network small and medium-sized firms. The aim was to make a systematic approach for analyzing financial statement. The data was collected from the public financial statements of the related firm. The proportion of each items in income statement and balance sheet were tested and identified for each firm. The paper was focused on eight measurement goals that associated to form profitability, resources, concentration, value, strategic map, productivity, risk and growth. Finally, various measures for each goal are suggested.

Uyar \& Kılıç (2012) focused on the Turkish listed companies by linking firm characteristics with voluntary disclosure of financial ratios in their annual reports. The population included a sample of manufacturing firms that listed in the Istanbul Stock 
Exchange. The annual reports of the companies were taken from the corporate websites. The detailed analysis was used to determine the disclosing financial ratio of the firms. The results shown that turkish listed companies demonstrate financial ratios by $\% 5.37$ on average in their annual reports. "Count data regression models" were utilized to test the hypotheses. The findings of multivariate evaluation show that profitability, firm size, ownership diffusion and auditor size have positive relationship with voluntary disclosure of financial ratios, while the leverage has a weak relationship with it.

\section{Research Methodology and Data Collection}

This section explains the research design and shows how to design the approach that is used to achieve the aim of the study. Also, it sets the method used in selecting respond. In the next step, the study describes the sample of population, which is collected from the financial statements of Kirkuk Company for producing constructional materials. Finally, the research focuses on the data analysis and shows that how to organized and analyzes the data of this study.

\section{Research Design}

The design of this study is imaginative research method. Both qualitative and quantitative methods were used in data collection and analysis. This paper employed with a case study approach which allows the researcher to conduct an intensive observations and investigation of salient factors in the units of study (Kothari, 1990).

\section{Data collection and analysis}

This study collected and grouped secondary data. The secondary data were achieved through the Iraqi Stock Exchange website which is published by the Kirkuk Company for producing constructional materials. The use of the data is a company's audited financial statements. The data period consisted of (2005-2011). The data were applied on the groups of financial ratios and calculated mathematically. After that, the data was analyzed, applied to the Microsoft Excel, SPSS and ANOVA Software to achieve the results. Respondents were selected randomly in each stratum. Hence, the researcher employed probability sampling technique to obtain the desired number of respondents (Mugenda \& Mugenda, 2003).

\section{Analysis and results discussion}

The results of the descriptive methods have been displayed through table no. 1 and no. 2 for the statistical analysis of financial statements that had been utilized for the analysis in this study and their correlation matrix as well. While, table no. 3, 4, and 5 reveal the trends of the regression model (Model Summary), Analysis of Variance and Test for Coefficients. The purpose of this study is to confirm the effect of financial statement analysis on profitability in the case of Kirkuk Company for producing constructional materials. The study utilizes descriptive research design. Secondary data is also used in this study. Microsoft Excel, ANOVA and Statistical Package for Social Sciences (IBM SPSS Software, V. 22) used to analyze the data in this study. The statistical techniques have being used such as Mean, Standard Deviation, Correlation, Regression, Model Summary, Analyzing of Variance and Coefficient. The data have being applied which consist of the periods of 2005, 2006, 2007, 2008, 2009, 2010 and 2011.

The statistical results show that, there is no relationship between profitability, liquidity, asset utilization and regulated utilization. In addition to this, the liquidity ratio, asset utilization ratio and regulated utilization ratio do not have any effect on the profitability 
for the Kirkuk Company for producing constructional materials. Meanwhile, each one of those variances has effect on the others. For example, the liquidity has an impact on the transactions of the company or any other activities. The liquidity also has an effect on the company's cash flow. If, the company becomes more and more liquid, they can develop their investment. More investment leads to more activities and then followed by making more profit for the company. Finally, the results of this study illustrate that, there is not relationship between the financial statement analysis for assessing the profitability in the Kirkuk Company for producing constructional materials. However, there is a weak relationship between the profitability and liquidity for the mentioned firm.

\section{Mean}

The most commonly used measurement for quantitative variable is the (arithmetic) sample mean. It can be shown as below:

Table 1 Descriptive Statistics

\begin{tabular}{|l|l|l|l|l|l|}
\hline & $\mathrm{N}$ & Minimum & Maximum & Mean & $\begin{array}{l}\text { Std. } \\
\text { Deviation }\end{array}$ \\
\hline Liquidity & 7 & $\mathbf{1 3 6 . 8 0}$ & $\mathbf{4 1 4 . 2 9}$ & $\mathbf{2 4 9 . 9 0 2 4}$ & $\mathbf{9 9 . 2 6 4 6 1}$ \\
\hline asset utilization & 7 & $\mathbf{4 . 0 9}$ & $\mathbf{2 1 7 . 4 6}$ & $\mathbf{7 6 . 1 8 3 0}$ & $\mathbf{7 9 . 7 8 9 7 3}$ \\
\hline Profitability & 7 & -4.58 & .25 & -1.1043 & 1.65548 \\
\hline $\begin{array}{l}\text { regulated } \\
\text { utilization }\end{array}$ & 7 & .14 & $\mathbf{2 . 0 3}$ & $\mathbf{. 8 5 3 3}$ & $\mathbf{. 6 4 4 4 6}$ \\
\hline $\begin{array}{l}\text { Valid N (list } \\
\text { wise) }\end{array}$ & 7 & \multicolumn{5}{|l|}{} \\
\hline
\end{tabular}

Table (1) presents the descriptive statistics for Kirkuk Company for producing constructional materials during the years $(2005,2006,2007,2008,2009,2010,2011)$, the statistical mean stand on negative (-1.1043) for profitability of the company which highlights the form of loss (net income negatively behaving ), meanwhile, others variables were positively behaving.

\section{Standard Deviation}

The sample standard deviation is the most frequently used measure of variability, although it is not as easily understood as ranges. It can be considered as a kind of average of the absolute deviations of observed values from the mean of the variable in question. Table (1) shows the standard deviation for liquidity is (99.26461), for asset utilization is (79.78973), for profitability is (1.65548) and for regulated utilization is $(0.64446)$. Meanwhile, the standard deviation $(\mathrm{sd})=\geq 0$.

\section{Correlation}

The sample correlation coefficient is also called as a Pearson correlation coefficient. As it is clear now that Pearson correlation coefficient can be calculated only when both variables are quantitative.

Table 2 Correlations

\begin{tabular}{|l|l|l|l|l|l|}
\hline \multicolumn{2}{|l|}{} & Liquidity & $\begin{array}{l}\text { asset } \\
\text { utilization }\end{array}$ & Profitability & $\begin{array}{l}\text { regulated } \\
\text { utilization }\end{array}$ \\
\hline Liquidity & $\begin{array}{l}\text { Pearson } \\
\text { Correlation }\end{array}$ & 1 & -.474 & -.606 & -.657 \\
\hline
\end{tabular}




\begin{tabular}{|c|c|c|c|c|c|}
\hline & Sig. (2-tailed) & & .282 & .149 & .109 \\
\hline & $\mathrm{N}$ & 7 & 7 & 7 & 7 \\
\hline \multirow[t]{3}{*}{$\begin{array}{l}\text { asset } \\
\text { utilization }\end{array}$} & $\begin{array}{l}\text { Pearson } \\
\text { Correlation }\end{array}$ & -.474 & 1 & .391 & .655 \\
\hline & Sig. (2-tailed) & .282 & & .386 & .110 \\
\hline & $\mathrm{N}$ & 7 & 7 & 7 & 7 \\
\hline \multirow[t]{3}{*}{ Profitability } & $\begin{array}{l}\text { Pearson } \\
\text { Correlation }\end{array}$ & -.606 & .391 & 1 & .653 \\
\hline & Sig. (2-tailed) & .149 & .386 & & .112 \\
\hline & $\mathrm{N}$ & 7 & 7 & 7 & 7 \\
\hline \multirow[t]{3}{*}{$\begin{array}{l}\text { regulated } \\
\text { utilization }\end{array}$} & $\begin{array}{l}\text { Pearson } \\
\text { Correlation }\end{array}$ & -.657 & .655 & .653 & 1 \\
\hline & Sig. (2-tailed) & .109 & .110 & .112 & \\
\hline & $\mathrm{N}$ & 7 & 7 & 7 & 7 \\
\hline
\end{tabular}

Source: computed by the author - using SPSS version 22

Table (2) displays the Pearson correlation and it is indicated to achieve the assessment of the ratios. According to this, the liquidity ratios are negatively behaving with asset utilization, profitability and regulated utilization. Meanwhile, all other used ratios were positively associated to each other, but not that much. Regulated utilization ratios are negatively related to liquidity with $(-0.657)$ which shows the shortage of cash (liquid asset) in the company. Therefore, the study may advice the company to keep enough cash for day- to day businesses. Profitability ratios have a low percentage of relationship (0.391) with asset utilization, which indicates that the management did not maximize the assets in the company. Lastly, the asset utilization has $(0.655)$ of correlation with the regulated asset.

\section{Regression}

The examination was directed to build up the relationship between the liquidity, asset utilization, profitability and regulated utilization in the Kirkuk Company. The analysis applied the statistical package for social sciences (SPSS) to register the estimations of the multiple regressions for the study. Below are the findings;

\section{a. Model Summary}

This model shows the summary of the regression analysis. Table (3) shows insignificant relationship among the variables, where R-Square stands on $48.6 \%$, which is moderate and the adjusted R Square that is negatively behaving with Durbin - Watson statistics. This indicates the absent of auto - correlation among the variables. Therefore, the table explains the percentage of variation in the dependent variable financial performance as explained by the independent variables.

The researcher used coefficient of determination ( $R$ Square) that is obtained from the model summary above. From the results of the analysis, the findings show that the independent variables contributed to $69.7 \%$ of the variation in organizational effectiveness as explained by adjusted R 2 of $-0.27 \%$ while the remain is explained by other variables outside the model and the error term.

Table 3 Model Summary

\begin{tabular}{|c|c|c|c|c|c|c|c|c|c|c|}
\hline \multirow[b]{2}{*}{$\begin{array}{l}\text { Mo } \\
\text { del }\end{array}$} & \multirow[t]{2}{*}{$\mathrm{R}$} & \multirow[b]{2}{*}{$\begin{array}{l}\mathrm{R} \\
\text { Square }\end{array}$} & \multirow[b]{2}{*}{$\begin{array}{l}\text { Adjusted } \\
\text { R Square }\end{array}$} & \multirow[b]{2}{*}{$\begin{array}{l}\text { Std. } \\
\text { Error of } \\
\text { the } \\
\text { Estimate }\end{array}$} & \multicolumn{5}{|c|}{ Change Statistics } & \multirow[b]{2}{*}{$\begin{array}{l}\text { Durbin- } \\
\text { Watson }\end{array}$} \\
\hline & & & & & $\begin{array}{l}\mathrm{R} \\
\text { Square } \\
\text { Change }\end{array}$ & $\begin{array}{l}\text { F } \\
\text { Cha } \\
\text { nge }\end{array}$ & $\begin{array}{l}\mathrm{df} \\
1\end{array}$ & $\begin{array}{l}\mathrm{df} \\
2\end{array}$ & $\begin{array}{l}\text { Sig. } \\
\text { F } \\
\text { Cha } \\
\text { nge }\end{array}$ & \\
\hline 1 & $\begin{array}{l}.69 \\
7^{a}\end{array}$ & .486 & -.027 & 1.67808 & .486 & .946 & 3 & 3 & .517 & 2.923 \\
\hline
\end{tabular}


a. Predictors: (Constant), regulated utilization, asset utilization, liquidity

b. Dependent Variable: profitability

Source: computed by the author - using SPSS version 22

\section{b. Analysis of Variance}

The study conducted an Analysis of Variance, in order to test the impact of the relationship between liquidity, asset utilization, profitability and regulated utilization in the Kirkuk Company. The findings were as shown below:

Table 4 ANOVA ${ }^{\mathrm{a}}$

\begin{tabular}{|l|l|l|l|l|l|l|}
\hline \multicolumn{2}{|l|}{ Model } & $\begin{array}{l}\text { Sum of } \\
\text { Squares }\end{array}$ & df & $\begin{array}{l}\text { Mean } \\
\text { Square }\end{array}$ & F & Sig. \\
\hline 1 & Regression & 7.996 & 3 & 2.665 & .946 & $.517^{\text {b }}$ \\
\cline { 2 - 7 } & Residual & 8.448 & 3 & 2.816 & & \\
\cline { 2 - 7 } & Total & 16.444 & 6 & & & \\
\hline
\end{tabular}

Source: computed by the author - using SPSS version 22

Table (4) shows the mean-square stands at 2.665 with $\mathrm{F}$ value of $94.6 \%$ which is insignificant at confidence level. This is because the $\mathrm{P}$ value is $51.7 \%$ which by far is more than (p-value 0.05).

\section{Test for Coefficients}

This table shows the level of significance on the variables, it also provides the standardized and unstandardized coefficients as shown below:

Table 5 Coefficients ${ }^{\mathrm{a}}$

\begin{tabular}{|c|c|c|c|c|c|c|c|c|c|}
\hline & & \multicolumn{2}{|c|}{$\begin{array}{l}\text { Unstandardized } \\
\text { Coefficients }\end{array}$} & \multirow{2}{*}{$\begin{array}{l}\begin{array}{l}\text { Standar } \\
\text { dized } \\
\text { Coeffici } \\
\text { ents }\end{array} \\
\text { Beta } \\
\end{array}$} & \multirow[b]{2}{*}{$\mathrm{T}$} & \multirow[b]{2}{*}{ Sig. } & \multicolumn{3}{|c|}{ Correlations } \\
\hline \multicolumn{2}{|c|}{ Model } & B & $\begin{array}{l}\text { Std. } \\
\text { Error }\end{array}$ & & & & $\begin{array}{l}\text { Zero- } \\
\text { order }\end{array}$ & $\begin{array}{l}\text { Part } \\
\text { ial }\end{array}$ & Part \\
\hline \multirow[t]{4}{*}{1} & (Constant) & -.741 & 3.286 & & $\begin{array}{l}- \\
.226\end{array}$ & .836 & & & \\
\hline & Liquidity & -.005 & .009 & -.318 & $\begin{array}{l}- \\
.577\end{array}$ & .604 & -.606 & $\begin{array}{l}- \\
.316\end{array}$ & $\begin{array}{l}- \\
.239 \\
\end{array}$ \\
\hline & $\begin{array}{l}\text { asset } \\
\text { utilization }\end{array}$ & -.002 & .011 & -.090 & $\begin{array}{l} \\
.163 \\
\end{array}$ & .881 & .391 & $\begin{array}{l}- \\
.094\end{array}$ & $\begin{array}{l}- \\
.067\end{array}$ \\
\hline & $\begin{array}{l}\text { regulated } \\
\text { utilization }\end{array}$ & 1.293 & 1.648 & .503 & .784 & .490 & .653 & .413 & .325 \\
\hline
\end{tabular}

Source: computed by the author - using SPSS version 22

Table (5) illustrates the standardized coefficient of liquidity, while representing beta equals $(-31.8 \%)$ and $(-0.9 \%)$ for asset utilization. Meanwhile, stand on (50.3\%) positively. 


\section{Conclusion}

The main objective of this paper is to determine the impact of analyzing the financial statement analysis on the profitability for the Kirkuk Company for producing constructional materials. Through fully investigating from all departments and checking factors and results, the study has narrowed to a result that using financial statement analysis may not affect the profitability in the company with respect that, the liquidity has a weak relationship with the profitability. Hence, there is insignificant relationship between the analyzing the financial statement and profitability in the Kirkuk Company. At the same times, there is a weak significant relationship from the liquidity to the profitability of the company. At the end, the paper comes to conclude that, the financial statement analysis may not important tools for assessing the profitability in the company. Through having an advanced system, the level of efficiency in timely manner, the profit will not increase in the company, there is a gap between the liquidity, asset utilization, regulated utilization and profitability with respect of the weak relationship between the liquidity and profitability.

\section{References}

Adebisi, A. E., Iyiola, A. A. \& Olayemi, A. A. (2016), The Statistical Evaluation of the Performance of Financial Ratio Analysis in Nigerian Manufacturing Industry: An Empirical Study of Guinness Nigeria PLC, The International Journal of Business \& Management, Vol. 4, No. 1, pp. 295-301.

Alani, F., Yaacob1 H. \& Hamdan, M. (2013), The Comparison of Financial Analysis Tools in Conventional and Islamic Banking: Evidence from Kuwait, International Journal of Business and Management, Vol. 8, No. 4, pp. 85-103. http://dx.doi.org/10.5539/ijbm.v8n4p85.

Barnes, P. (1987), The Analysis and Use of Financial Ratios: A Review Article, Journal of Business Finance \& Accounting, Vol. 14, No. 4, pp. 449-461. https://doi.org/10.1111/j.1468-5957.1987.tb00106.

Berry, R. H. \& Nix, S. (2012), Regression Analysis v. Ratios in the Cross-section Analysis of Financial Statements, Accounting and Business Research, Vol. 21, No. 82, pp. 107-117. https://doi.org/10.1080/00014788.1991.9729823.

Bodie, Z., Robert C. M., \& David L. C. (2009), Financial Economics, 2nd edition, Person Prentice Hall, London.

Bragg, S. M. (2012), Business ratios and formulas: a comprehensive guide, 3rd edition, John Wiley \& Sons, New York, United States.

Brigham, E., \& Houston, J. (2015), Fundamentals of Financial Management, 8th edition, South Western, Cengage Learning, United States.

Costea, c. d. \& Hostiuc, F. (2009), The liquidity ratios and their significance in the financial, The Annals of The "Ştefan cel Mare" University Suceava, Fascicle of The Faculty of Economics and Public Administration, Vol. 9, No.1 (9), pp. 252261.

Dauderis, H. \& Annand, D. (2014), Introduction to Financial Accounting, 2nd edition, Valley Educational Services Ltd. Athabasca.

Gadoiu, M. (2014), Advantages And Limitations Of The Financial Ratios Used In The Financial Diagnosis Of The Enterprise, Scientific Bulletin - Economic Sciences, University of Pitesti, vol. 13 (2), pp. 87-95.

Gautam, K. R. (2013), Structure and Utilization of Receivable of Listed NonGovernment Manufacturing Companies in Nepal, Janapriya Journal of Interdisciplinary Studies, Vol. 2, No.1, PP. 65-72.

http://dx.doi.org/10.3126/jjis.v2i1.18068. 
Gibson, C. (2013), Financial Reporting and Analysis Using Financial Accounting Information, 13th edition. South Western, Cengage Learning, United States.

Gill, J. (1999), Understanding financial statements a primer of useful information, Revised Edition, Crisp Learning publisher, New York.

Lasher, W. R. (1997), Advanced financial Accounting, 5th edition, Pitman publishing co. London.

Laitinen, E. K. (2006), Financial Statement Analysis of a Network of SMEs: towards measurement of Network Performance, International Journal of Networking and Virtual Organizations, Vol. 3, No.3, pp. $258-282$.

Maggina, A. G. (2008), On the Distributional Properties of Financial Ratios in Annual Reports of Greek listed Companies, International Journal of Managerial and Financial Accounting, Vol. 1, No.2, pp. 166-183. doi>10.1504/IJNVO.2006.010951.

Mc Donald, B. \& Morris, M. H. (1985), The Functional Specification of Financial Ratios: An Empirical Examination, Accounting and Business Research, Vol. 15, pg. 223- 228. https://doi.org/10.1080/00014788.1985.9729267.

Mugenda, O. M. \& Mugenda, A. G. (2003), Research methods: Quantitative and qualitative Approaches, Nairobi: African Centre for Technology Studies, available at https://doi.org/10.12691/education-2-11A-5.

Nuhu, M. (2014), Role of Ratio Analysis in Business Decisions: A Case Study NBC Maiduguri Plant, Journal of Educational and Social Research, Vol. 4, No.5, pp. 105-118, available at https://doi.org/10.5901/jesr.2014.v4n5p105.

Omari, L. \& Al Omari, R. (2015), The Impact of Activity Ratios among Industrial Sectors' Performance: Jordanian Case, Research Journal of Finance and Accounting, Vol.6, No.6, pp. 173-178.

Kijewska. (2016), Determinants of the return on equity ratio (roe) on the example of companies from metallurgy and mining sector in Poland, Journal Metalurgija, Vol. 55, No. 2, pp. 285-288.

Kothari, C. R. (1990), Research Methodology: Methods and Techniques, Second revised edition, New Age International Publisher, New Delhi.

Rashid, C.A. (2018), Efficiency of Financial Ratios Analysis for Evaluating Companies' Liquidity, International Journal of Social Sciences \& Educational Studies, Vol.4, No.4, pp. 110-123. https://doi.org/10.23918/ijsses.v4i4p110.

Ravinder, D. \& Anitha, M. (2013), Financial Analysis, Journal of Economics and Finance, Vol. 2, No. 3, pp 10-22.

Ross, S. A., Westerfield, R. W. \& Jordan, J. (2013), Fundamentals Corporate Finance, 1st Middle East edition, Mc Graw- Hill.

Shilpa, T., Aruna, A., \& Vardhan,V. H. (2017), Role Of Ratio Analysis In Business Decisions, International Journal of Scientific \& Engineering Research, Vol. 8, No. 5, pp. 231-236.

Sultan, A. S. (2014), Financial Statements Analysis - Measurement of Performance and Profitability: Applied Study of Baghdad Soft-Drink Industry, Research Journal of Finance and Accounting, Vol. 5, No. 4, pp. 49-56.

Tugas, F.C. (2012), A Comparative Analysis of the Financial Ratios of Listed Firms Belonging to the Education Subsector in the Philippines for the Years 20092011, International Journal of Business and Social Science, Vol. 3, No. 21, pp. 173-190.

Tulsian, M. (2014), Profitability Analysis (A comparative study of SAIL \& TATA), Journal of Economics and Finance, Vol. 3, No. 2, pp 19-22.

Uyar, A. \& Kılıç, M. (2012), The Influence of Firm Characteristics on Disclosure of Financial Ratios in Annual Reports of Turkish firms listed in the Istanbul Stock 
Ahmed

Exchange, International Journal of Accounting, Auditing and Performance Evaluation, Vol. 8, No.2, pp. 137 - 156.

https://doi.org/10.1504/IJAAPE.2012.046603. 